\title{
PENGARUH STRES KERJA, KOMUNIKASI DAN LINGKUNGAN KERJA TERHADAP KEPUASAN KERJA KARYAWAN PADA KANTOR PT. PLN (PERSERO) CILACAP JAWA TENGAH
}

\author{
Irna Sari Pratiwi \\ Fakultas Ekonomi Universitas Muhammadiyah Purwokerto \\ Hermin Endratno \\ Fakultas Ekonomi Universitas Muhammadiyah Purwokerto
}

\begin{abstract}
This research was aimed at examining the impact of job stress, communication and work environment on employee job satisfaction in PT. PLN (Persero) Cilacap Jawa Tengah.

The object of this research was the employees of PT. PLN (Persero) Cilacap Jawa Tengah, namely: PLN APJ Cilacap, UPJ Sidareja and UPJ Majenang. The total number was 85 persons (census). This research applied multiple regression analysis, $T$ test and $T$ test.

The study results revealed that job stress was negatively related to employee satisfaction, while communication and work environment positively affected employee job satisfaction in PT. PLN (Persero) Cilacap Jawa Tengah.
\end{abstract}

Keywords: Job Stress, Communication, Work Environment, Job Satisfaction

\begin{abstract}
ABSTRAK
Penelitian ini bermaksud untuk menguji Pengaruh Stres Kerja, Komunikasi Dan Lingkungan Kerja Terhadap Kepuasan Kerja Karyawan Pada Kantor Pt. Pln (Persero) Cilacap Jawa Tengah.

Objek penelitian ini adalah karyawan PT. PLN (Persero) Cilacap Jawa Tengah, yaitu: PLN APJ Cilacap, UPJ Sidareja dan UPJ Majenang. Jumlah total adalah 85 orang (sensus). Penelitian ini menggunakan analisis regresi berganda dan uji $\mathrm{T}$.

Hasil penelitian menunjukkan bahwa stres kerja berhubungan negatif dengan kepuasan karyawan, sementara komunikasi dan lingkungan kerja yang memiliki dampak positif terhadap kepuasan kerja karyawan di PT. PLN (Persero) Cilacap Jawa Tengah.
\end{abstract}

Kata Kunci: Stres Kerja, Komunikasi, Lingkungan Kerja, Kepuasan Kerja 


\section{PENDAHULUAN}

\section{A. Latar Belakang}

Sebagai badan yang strategis bagi perekonomian bangsa, PLN dituntut untuk mencapai pelayanan kelistrikan bagi semua sektor pembangunan termasuk rumah tangga. Untuk itu perlu ada dukungan dari karyawan PLN yang professional dalam mewujudkan kesuksesan PLN namun, terkadang ada masalah yang terjadi dalam mewujudkan itu semua seperti komplain dari para pelanggan listrik apabila ada pemadaman bergilir yang dilakukan oleh PLN. Hal tersebut tentu mempengaruhi kinerja karyawan PLN yang dituntut sempurna ketika melayani pelanggannya.

Beberapa penelitian menunjukkan bahwa kepuasan kerja sangat mempengaruhi kinerja karyawan. Penelitian yang diakukan oleh Rosita (2012) mengambil objek di SMPN 1 Rantau Selatan menunjukkan hasil adanya pengaruh yang signifikan antara kepuasan kerja terhadap kinerja karyawan. Menurut Yuli (2013) mengambil objek di PT. Tunas Hijau Samarinda menunjukkan hasil yang signifikan terhadap kepuasan kerja karyawan. Serta penelitian yang dilakukan Didik (2009) objeknya di Rumah Sakit Umum Daerah Sukoharjo juga menunjukkan hasil kepuasan kerja mempengaruhi kinerja karyawan. Melihat pentingnya aspek sumber daya manusia dalam Perusahaan Listrk Negara (PLN) dan pentingnya pengaruh beberapa faktor stres kerja dan komunikasi terhadap kepuasan kerja, maka penulis tertarik untuk melakukan penelitian dengan judul "PENGARUH STRES KERJA, KOMUNIKASI, DAN LINGKUNGAN KERJA TERHADAP KEPUASAN KERJA KARYAWAN PADA KANTOR PT. PLN (PERSERO) CILACAP JAWA TENGAH".

\section{Tujuan Penelitian}

1. Untuk menguji secara simultan pengaruh stres kerja, komunikasi dan lingkungan kerja terhadap kepuasan kerja karyawan PT. PLN (Persero) Cilacap.

2. Untuk menguji pengaruh stres kerja terhadap kepuasan kerja karyawan PT. PLN (Persero) Cilacap.

3. Untuk menguji pengaruh komunikasi terhadap kepuasan kerja karyawan PT. PLN (Persero) Cilacap.

4. Untuk menguji lingkungan kerja terhadap kepuasan kerja karyawan PT. PLN (Persero) Cilacap.

\section{B. Kerangka Pemikiran}

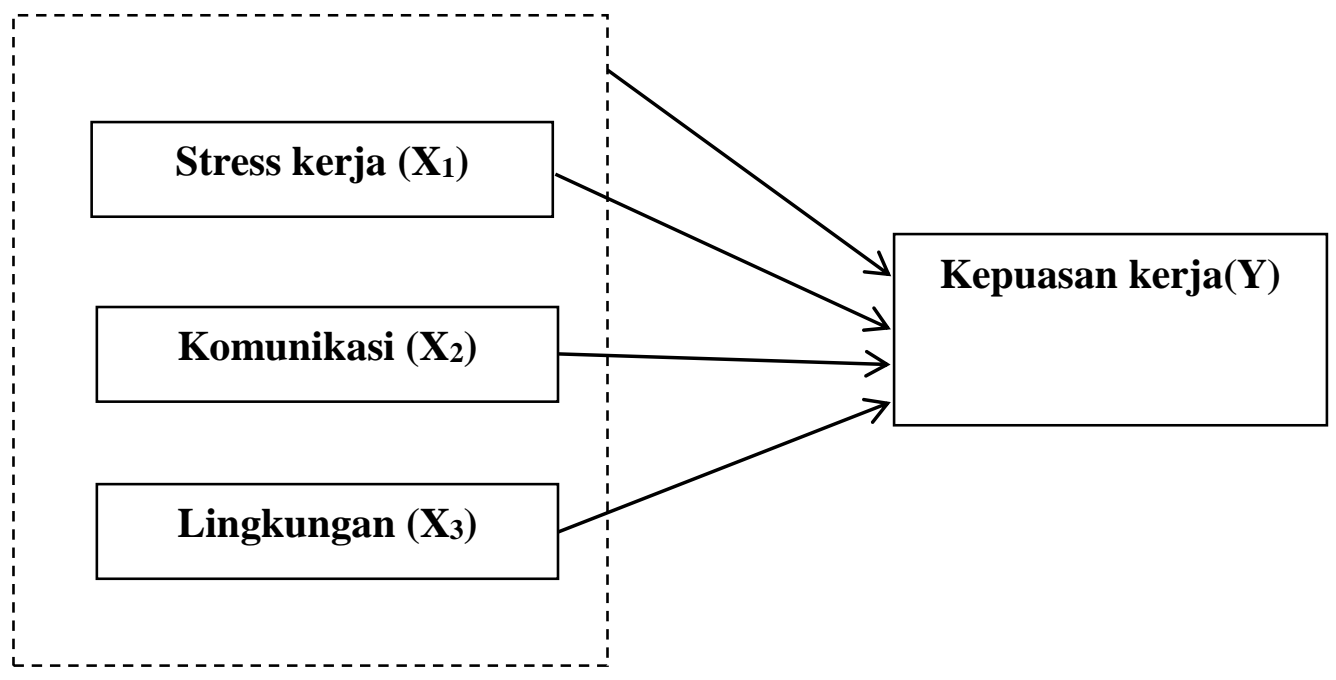

Gambar 1. Kerangka pemikiran 


\section{Hipotesis}

Berdasarkan permasalahan dan teori-teori yang telah dikemukakan di sub bab sebelumnya, maka penelitian ini mengambil hipotesis sebagai berikut:

Hipotesis $1\left(\mathrm{H}_{1}\right)$

Stres kerja, komunikasi dan lingkungan kerja secara simultan berpengaruh terhadap kepuasan kerja.

Hipotesis $2\left(\mathrm{H}_{2}\right)$

Stres kerja berpengaruh signifikan terhadap kepuasan kerja.

Hipotesis $3\left(\mathrm{H}_{3}\right)$

Komunikasi berpengaruh signifikan terhadap kepuasan kerja.

Hipotesis $4\left(\mathrm{H}_{4}\right)$

Lingkungan kerja berpengaruh signifikan terhadap kepuasan kerja.

\section{METODE PENELITIAN}

\section{A. Jenis Penelitian}

Pada penelitian ini, jenis penelitian yang digunakan adalah metode survey yaitu penelitian yang mengambil sampel dari satu populasi dan menggunakan kuesioner sebagai alat pengumpul data yang pokok.

\section{B. Objek Penelitian}

Objek penelitian dalam penelitian ini adalah di PT. PLN (Persero) Cilacap yaitu PLN APJ Cilacap, UPJ Sidareja, dan UPJ Majenang yang berjumalah 85 orang terdiri dari 45 karyawan APJ Cilacap, 20 karyawan UPJ Sidareja, dan 20 UPJ Majenang.

\section{Metode Pengambilan Sampel}

Menurut Arikunto (2002) untuk sampel apabila subjeknya kurang dari 100 lebih baik diambil semua sehingga penelitiannya merupakan penelitian populasi. Metode pengambilan sampel yang digunakan dalam penelitian ini adalah metode sensus yaitu pengambilan sampel dengan cara semua anggota populasi dijadikan sampel jenuh, yaitu karyawan di PT. PLN (Persero) Cilacap

\section{Metode Analisis Data}

Pada penelitian ini menggunakan regresi linier berganda

\section{E. Definisi Operasional}

\section{Pengertian Kepuasan Kerja}

Menurut Hasibuan (2007) kepuasan kerja adalah sikap emosional yang menyenangkan dan mencintai pekerjaannya.

Indikator kepuasan kerja menurut Hasibuan (2007) adalah sebaga berikut:

a. Balas jasa yang adil dan layak.

b. Penempatan yang tepat sesuai dengan keahlian.

c. Berat-ringannya pekerjaan

d. Suasana dan lingkungan pekerjaan.

e. Peralatan yang menunjang pelaksanaan pekerjaan.

f. Sikap pimpinan dalam kepemimpinannya.

g. Sifat pekerjaan monoton atau tidak.

\section{Pengertian Stres Kerja}

Menurut Davis \& Newstrom (1985) stres adalah suatu kondisi ketegangan yang mempengaruhi emosi, proses pikiran, dan kondisi fisik seseorang. 
Menurut Robbins (2006) indikator stres kerja adalah sebagai berikut:

a. Tuntutan tugas, merupakan faktor yang dikaitkan pada pekerjaan seseorang seperti kondisi kerja, tata kerja, dan letak fisik.

b. Tuntutan peran, berhubungan dengan tekanan yang diberikan pada seseorang sebagai suatu fungsi dari peran tertentu yang dimainkan dalam suatu organisasi.

c. Tuntutan antar pribadi, merupakan tekanan yang diciptakan oleh pegawai lain

d. Struktur organisasi

e. Kepemimpinan organisasi

\section{Pengertian Komunikasi}

Menurut Marwansyah (2010) komunikasi adalah "the transfer and understanding of meaning" (pemindahan dan pemahaman makna).

Indikator komunikasi menurut Rahmat (2000) pada Utami (2010) sebagai berikut:

a) Pengertian, yaitu pemahaman dan penerimaan yang cermat terhadap isi pesan seperti yang dimaksud komunikator.

b) Kesenangan, yaitu bahwa dengan berkomunikasi akan menimbulkan rasa senang dan puas bagi pihak-pihak yang berkomunikasi.

c) Mampu merubah sikap, artinya komunikasi yang dilakukan dapat mempengaruhi sikap peserta komunikasi sesuai dengan isi pesan.

d) Hubungan sosial yang baik, maksudnya komunikasi bertujuan menumbuhkan dan mengembangkan hubungan sosial kearah yang lebih baik.

e) Tindakan, merupakan hasil akhir dari proses komunikasi yang efektif, menimbulkan tindakan nyata dan positif.

\section{Pengertian Lingkungan Kerja}

Menurut Nitisemito (1996) lingkungan kerja adalah segala sesuatu yang ada di sekitar pekerja dan yang dapat mempengaruhi dirinya dalam menjalankan tugastugas yang dibebankan. Misalnya kebersihan dan musik.

Menurut Sedarmayanti (2007), yang menjadi indikator-indikator lingkungan kerja adalah:
a. Penerangan yang cukup
b. Sirkulasi udara yang terjaga
c. Kebersihan yang baik
d. Peralatan kantor yang lengkap
e. Keamanan kerja yang terjaga
f. Hubungan sesama rekan kerja
g. Hubungan kerja antara atasan dengan bawahan

\section{HASIL PENELITIAN DAN PEMBHASAN}

\section{A. Respon Rate}

Kuisioner yang disebarkan sejumlah 85 eksemplar sedangkan yang kembali dan dianalisis berjumlah 84 eksemplar

\section{B. Uji Validitas}

Validitas instrument penelitian ini dapat dilihat dari nilai signifikansi. Jika nilai signifikansi kurang dari 0,05 maka item pertanyaan dikatakan valid, jika nilai signifikansi lebih dari 0,05 maka item pertanyaan tidak valid 


\section{Uji Hipotesis}

\section{Hipotesis Pertama}

Tabel 3.1 Hasil Uji F

\begin{tabular}{|rr|r|r|r|r|r|}
\hline \multicolumn{7}{|c|}{ ANOVA $^{\mathbf{b}}$} \\
\hline 1 & Sum of Squares & df & Mean Square & F & \multicolumn{1}{c|}{ Sig. } \\
\hline & Regression & $1.031 \mathrm{E} 7$ & 3 & 3435840.332 & 23.283 & $.000^{\mathrm{a}}$ \\
& Residual & $1.181 \mathrm{E} 7$ & 80 & 147568.174 & & \\
& Total & $2.211 \mathrm{E} 7$ & 83 & & & \\
\hline
\end{tabular}

a. Predictors: (Constant), Lingkungan_Kerja, Stres_Kerja, Komunikasi

b. Dependent Variable: Kepuasan_Kerja

1

Nilai $F_{\text {hitung }}$ pada model penelitian diketahui sebesar 23,283 sedangkan $F_{\text {tabel }}$ sebesar 2,719 sehingga diketahui $F_{\text {hitung }}>F_{\text {tabel }}$ yaitu 23,283 $>$ 2,719 serta dengan taraf signifikansi sebesar 0,000 . Nilai signifikansi berada di bawah 0,05 yang menunjukkan bahwa $\mathrm{H}_{\mathrm{o}}$ ditolak dan menerima $\mathrm{H}_{\mathrm{a}}$. Artinya stres kerja, komunikasi, dan lingkungan kerja secara simultan berpengaruh signifikan terhadap kepuasan kerja, sehingga hipotesis pertama diterima.

\section{Pembuktian Hipotesis Kedua}

Tabel 3.2 Hasil Uji T

\begin{tabular}{|c|c|c|c|c|c|}
\hline \multirow[b]{2}{*}{ Model } & \multicolumn{2}{|c|}{ Unstandardized Coefficients } & \multirow{2}{*}{$\begin{array}{c}\begin{array}{c}\text { Standardized } \\
\text { Coefficients }\end{array} \\
\text { Beta }\end{array}$} & \multirow[b]{2}{*}{$\mathrm{t}$} & \multirow[b]{2}{*}{ Sig. } \\
\hline & B & Std. Error & & & \\
\hline 1(Constant) & 227.522 & 495.556 & & .459 & .647 \\
\hline Stres_Kerja & -.013 & .072 & -.015 & -.184 & .854 \\
\hline Komunikasi & .649 & .100 & .582 & 6.482 & .000 \\
\hline Lingkungan_Kerja & .205 & .098 & .188 & 2.088 & .040 \\
\hline
\end{tabular}

a. Dependent Variable: Kepuasan_Kerja

Berdasarkan tabel tersebut diketahui bahwa variabel stres kerja memiliki nilai $t_{\text {hitung }}$ sebesar $-0,13$ sedangkan nilai $t_{\text {tabel }}$ sebesar 1,990 dengan demikian $\mathrm{t}_{\text {hitung }}<\mathrm{t}_{\text {tabel }}$ yaitu $-0,184<1,990$ serta nilai signifikan sebesar 0,854 lebih dari 0,05 . Hal ini berarti hipotesis 2 yang berbunyi stres kerja tidak berpengaruh signifikan terhadap kepuasan kerja dengan demikian hipotesis kedua ditolak. 


\section{Hipotesis ketiga}

Hipotesis ketiga dilakukan untuk menguji pengaruh komunikasi terhadap kepuasan kerja. Nilai $t_{\text {hitung }}$ sebesar 6,482 sedangkan nilai $t_{\text {tabel }}$ sebesar 1,990 dengan demikian $t_{\text {hitung }}>t_{\text {tabel }}$ yaitu $6,482>1,990$ serta nilai signifikan sebesar 0,000 kurang dari 0,05. Hal ini berarti hipotesis ketiga komunikasi berpengaruh secara signifikan terhadap kepuasan kerja dengan demikian hipotesis ketiga diterima.

\section{Hipotesis Keempat}

Berdasarkan tabel tersebut diketahui bahwa variabel lingkungan kerja memiliki nilai $t_{\text {hitung }}$ sebesar 2,088 sedangkan nilai tabel sebesar 1,990 dengan demikian $t_{\text {hitung }}>\mathrm{t}_{\text {tabel }}$ yaitu 2,088 $>1,990$ serta nilai signifikan sebesar 0,40 kurang dari 0,05 . Hal ini berarti hipotesis lingkungan kerja berpengaruh signifikan terhadap kepuasan kerja dengan demikian hipotesis keempat diterima.

Koefisien Determinasi

\begin{tabular}{|l|r|r|r|r|r|}
\hline \multicolumn{1}{|c|}{ Model $^{\text {Model Summary }}$} \\
\hline 1 & $\mathrm{R}$ & R Square & $\begin{array}{c}\text { Adjusted R } \\
\text { Square }\end{array}$ & $\begin{array}{c}\text { Std. Error of the } \\
\text { Estimate }\end{array}$ & Durbin-Watson \\
\hline 1 & $.683^{\mathrm{a}}$ & .466 & .446 & 384.14603 & 1.640 \\
\hline
\end{tabular}

a. Predictors: (Constant), Lingkungan_Kerja, Stres_Kerja, Komunikasi

b. Dependent Variable: Kepuasan_Kerja

Berdasarkankan hasil output spss diatas dapat dilihat bahwa nilai dari koefisien determinasi (Adjusted $R^{2}$ ) sebesar 0,446. Hal ini berarti 44,6\% variabel kepuasan kerja dapat dijelaskan dari ketiga variabel independen yaitu stres kerja, komunikasi, dan lingkungan kerja. Sedangkan selisihnya sebesar 55,4\% dijelaskan oleh sebab lain di luar model (di luar penelitian ini) misalnya kepemimpinan (Paramarta 2012), kepemimpinan dan budaya organisasi (Brahmasari dan Suprayetno 2008).

\section{PEMBAHASAN}

Dalam penelitian ini terdapat hal yang perlu dipertimbangkan sebagai bagian dari kelemahan penelitian ini yaitu variabel yang diteliti dalam penelitian ini belum mampu menjelaskan semua tentang kepuasan kerja karyawan, sehingga perlu menggali variabel lain yang dapat mempengaruhi. Hal ini terlihat pada adjusted $R^{2}$ yang bernilai 0,446 . Hal ini berarti $44,6 \%$ stres kerja, komunikasi, dan lingkungan kerja. Sisanya 55,4 \% dijelaskan oleh sebab lain di luar model (di luar penelitian ini) misalnya kepemimpinan dan budaya organisasi (Suprayetno dan Brahmasari 2008)

\section{KESIMPULAN, SARAN DAN KETERBATASAN PENELITIAN}

\section{A. Kesimpulan}

Berdasarkan analisis yang telah dilakukan, maka ditarik beberapa kesimpulan diantaranya adalah: 
1. Stres kerja, komunikasi, dan lingkungan kerja secara simultan berpengaruh signifikan terhadap kepuasan kerja karyawan. Hal ini ditunjukkan dengan nilai $\mathrm{F}_{\text {hitung }}>\mathrm{F}_{\text {tabel }}$ yaitu 23,283 $>2,719$ serta nilai signifikansi sebesar 0,000. Nilai signifikansi berada dibawah 0,05 .

2. Stres kerja secara parsial tidak berpengaruh signifikan terhadap kepuasan kerja karyawan. Hal ini ditunjukkan dengan nilai $t_{\text {hitung }}<t_{\text {tabel }}$ yaitu $-0,13<1,990$ serta nilai signifikan sebesar 0,854 lebih dari 0,05.

3. Komunikasi secara parsial berpengaruh signifikan terhadap kepuasan kerja karyawan. Hal ini ditunjukkan dengan nilai $t_{\text {hitung }}>t_{\text {tabel }}$ yaitu 6,482 $>1,990$ serta nilai signifikan sebesar 0,000 kurang dari 0,05.

4. Lingkungan kerja secara parsial berpengaruh signifikan terhadap kepuasan kerja karyawan. Hal ini ditunjukkan dengan nilai $t_{\text {hitung }}>t_{\text {tabel }}$ yaitu 2,088 $>1,990$ serta nilai signifikan sebesar 0,40 kurang dari 0,05 .

\section{Saran}

1. Meskipun stres kerja tidak signifikan, PT. PLN seyogyanya tetap memperhatikan agar stres kerja tidak menimbulkan dampak pada kepuasan kerja di masa datang. Pimpinan PT. PLN (Persero) Cilacap sebaiknya lebih meningkatkan kepuasan kerja karyawan dengan cara mengurangi stres kerja karyawan dengan cara mengadakan liburan yang diperuntukan kepada para karyawan guna mengurangi kejenuhan didalam menjalani aktivitas kerjanya. Dengan begitu kondisi jiwa para karyawan dapat lebih baik lagi dan dapat bekerja secara optimal, diadakan sharing antar karyawan, diperbanyak taman hijau (di luar tempat kerja) untuk menambah keasrian lingkungan kerja karyawan.

2. Pada penelitian selanjutnya diharapkan dapat menambah variabel lain yang dapat meningkatkan kepuasan kerja.

\section{Keterbatasan Penelitian}

Dalam penelitian masih terdapat banyak keterbatasan penelitian yang dapat mempengaruhi hasil penelitian, yaitu:

1. Nilai adjusted $R^{2}=0,446$ belum bernilai 1 sehingga masih ada faktor lain yang mempengaruhi kepuasan kerja PT. PLN (Peresero) Cilacap perlu digali kembali.

2. Penelitian ini hanya mengambil 1 objek yaitu PT. PLN (Persero) Cilacap sehingga hasil penelitian belum dapat diterapkan pada objek yang lain (belum dapat digeneralisasi).

\section{Daftar Pustaka}

Arikunto, Suharsini. 2002. Prosedur Penelitian Suatu Pendekatan Praktek, Edisi Revisi V Cetakan ke Dua Belas. Rineka Cipta: Bandung.

Bestiana, Rosita. 2012. Hubungan Kepuasan Kerja, Motivasi dan Komitmen Normativ dengan Kinerja Guru SMPN 1 Rantau Selatan-Labuhan Batu. Jurnal Tabularasa PPS Unimed, Vol. 9 No. 2, Desember 2012.

Davis, Keith \& Newstrom, John. W. 1985. Perilaku Dalam Organisasi Jilid 2, $\quad$ Erlangga, Jakarta.

Hasibuan, S.P., Malayu, 2007. Manajemen Sumber Daya Manusia, PT Bhumi Aksara, Jakarta.

Nitisemito, Alex, S. 1996. Manajemen Personalia. UGM: Yogyakarta. 
Paripurna, I Gede, Diatmika. 2012. Pengaruh Kepemimpinan, Lingkungan Kerja, dan Komunikasi terhadap Kepuasan Kerja Karyawan. Jurnal Fakultas Ekonomi Universitas Udayana Bali.

Sedarmayanti, 2007. Manajemen Sumber Daya Manusia, Penerbit Refika Aditama, Bandung.

Setyawan, Didik. 2009. Pengaruh Kepuasan Kerja Terhadap Kinerja Karyawan Dengan Komitmen Organisasional Sebagai Variabel Intervening Dan Pengaruh Etika Kerja Terhadap Kinerja Karyawan. Jurnal Bisnis dan Kewirausahaan, Vol 2 No. 4 Oktober 2009.

Suprayetno, Agus dan Brahmasari, Ida, Ayu. 2008. Pengaruh Motivasi Kerja, Kepemimpinan dan Budaya Organisasi Terhadap Kepuasan Kerja Karyawan serta Dampaknya pada Kinerja Perusahaan (Studi Kasus pada PT. Hai International Wiratama Indonesia). Jurnal Manajemen dan Kewirausahaan, Vol. 10, No. 2 September 2008.

Suwati, Yuli. 2013. Pengaruh Kompensasi dan Motivasi Kerja Terhadap Kinerja Karyawan Pada PT. Tunas Hijau Samarinda. Jurnal eJournal Ilmu Administrasi Bisnis, 2013.

Utami, Setyaningsih. Sri. 2010, Pengaruh kepemimpinan, motivasi, komunikasi, dan lingkungan kerja terhadap kinerja pegawai kecamatan Jumantono Kabupaten Karanganyar. Jurnal Manajemen SDM Vol. 4 No.1. Juni 2010.

\section{Sumber Internet}

http://jurnal-sdm.blogspot.com/2009/09/indikator-untuk-mengukur-kepusan-kerja.html 